\title{
Purification and Characterization of Lysosomal $\beta$-Glucuronidase from Human Placenta
}

\author{
By S. F. CONTRACTOR and B. SHANE \\ Department of Obstetrics and Gynaecology, Charing Cross Hospital Medical School, \\ London W.C.2, U.K.
}

(Received 20 January 1972)

\begin{abstract}
1. Subcellular fractions of human placenta were prepared by nitrogen-bomb homogenization and differential centrifugation. 2. $\beta$-Glucuronidase from placental lysosomes was purified 2100 -fold on a protein basis. 3 . The lysosomal enzyme, at different stages of purification, was characterized by using 4-methylumbelliferyl $\beta$-D-glucuronide and phenolphthalein $\beta$-D-glucuronide as substrates. 4. Only one isoenzyme of $\beta$-glucuronidase was found in placenta; the enzyme in the endoplasmic reticulum appeared to be the same as the lysosomal enzyme. 5. The isoenzyme contained in normal plasma was different from that of the placenta. 6 . The elevated $\beta$-glucuronidase activity found in plasma obtained during pregnancy was due to increased activity of the normal plasma isoenzyme; no contribution was made by placental isoenzyme. 7. Plasma contained a heat-stable, non-diffusible activator of placental $\beta$-glucuronidase. 8. A heat-stable competitive inhibitor of placental and plasma $\beta$-glucuronidase was also present in plasma.
\end{abstract}

Fishman (1967) has reviewed several reports of elevated serum $\beta$-glucuronidase $(\beta$-D-glucuronide glucuronohydrolase, EC 3.2.1.31) activity during pregnancy and has suggested that this increase may be due to placental contribution of the enzyme to the maternal circulation. Our basic interest in this study was to investigate whether placental isoenzymes of $\beta$-glucuronidase were present in maternal blood and, if so, whether the concentration of such isoenzymes could be correlated with gestational age or placental function.

We are also interested in the development of enzymes of placental lysosomes, so an attempt was made to purify lysosomal $\beta$-glucuronidase, and the properties and distribution of the enzyme in the placenta were investigated.

\section{Materials and Methods}

\section{Materials}

Human placentae were obtained from term and hysterotomy patients. Phenolphthalein $\beta$-D-glucuronide was prepared from phenolphthalein diphosphate (BDH Chemicals Ltd., Poole, Dorset, U.K.) by the method of Levvy \& Marsh (1959). 4-Methylumbelliferyl $\beta$-D-glucuronide, $3 \mathrm{H}_{2} \mathrm{O}$ and 4-methylumbelliferone were obtained from Koch-Light Laboratories Ltd., Colnbrook, Bucks., U.K. Bovine serum albumin and Triton X-100 were obtained from Sigma (London) Chemical Co. Ltd., London S.W.6, U.K. DEAE-Sephadex A-50 and Sephadex G-100 were obtained from Pharmacia (G.B.) Ltd., London W.5, U.K. DEAE-cellulose DE52 was obtained from $H$. Reeve Angel and Co. Ltd., London E.C.4, U.K. The nitrogen-bomb pressure homogenizer was made by Baskerville and Lindsay Ltd., Manchester, U.K.

\section{Preparation of lysosomal fraction}

Lysosomal fractions were prepared by a modification of the method of Contractor (1969). All procedures were done at $0-4^{\circ} \mathrm{C}$.

Freshly delivered placenta was washed in $0.9 \%$ $\mathrm{NaCl}$ to remove as much blood as possible and the surface moisture was blotted. Non-fibrous areas free of calcium deposits and gross infarcts were snipped off in small pieces and about $50 \mathrm{~g}$ of tissue was forced through a coarse steel mesh $(1.3 \mathrm{~mm}$ diam.) and then through a fine mesh $(0.6 \mathrm{~mm}$ diam.) with a tissue mincer (Climpex Ltd., Hammers Lane, London N.W.7, U.K.). A portion of the brei $(36 \mathrm{~g})$ was suspended in $0.25 \mathrm{M}$-sucrose, buffered to $\mathrm{pH} 7$ with tris and containing $0.34 \mathrm{~mm}$-EDTA $(500 \mathrm{ml})$, and was homogenized in a nitrogen bomb at a pressure of $6.9 \mathrm{MN} / \mathrm{m}^{2}\left(1000 \mathrm{lbf} / \mathrm{in}^{2}\right)$ for $10 \mathrm{~min}$.

The homogenate was centrifuged at $600 \mathrm{~g}$ for $10 \mathrm{~min}$ to give a nuclear pellet and the supernatant was filtered through nylon mesh monofilament 4499-H25 (John Staniar and Co., Manchester, U.K.) and centrifuged at $20000 \mathrm{~g}$ for $20 \mathrm{~min}$. The supernatant was termed the post-lysosomal fraction. The resulting lysosomal pellet was washed with $0.5 \mathrm{vol}$. of $0.25 \mathrm{M}$ sucrose and re-centrifuged for the same $g$-min. 
The washed pellet was suspended in about $20 \mathrm{ml}$ of $0.1 \%$ Triton X-100. Before further purification the cell debris were removed by centrifugation at $40000 \mathrm{~g}$ for $30 \mathrm{~min}$.

\section{Assay of $\beta$-glucuronidase}

$\beta$-Glucuronidase was determined by using 4methylumbelliferyl $\beta$-D-glucuronide or phenolphthalein $\beta$-D-glucuronide as substrate.

Assay with methylumbelliferyl glucuronide. The method used was a modification of Woollen \& Turner's (1965) method for plasma.

Enzyme solution $(0.1 \mathrm{ml})$ was preincubated with $0.2 \mathrm{M}$-sodium acetate buffer, $\mathrm{pH} 3(0.2 \mathrm{ml})$, and water $(0.5 \mathrm{ml})$. Substrate $(0.2 \mathrm{ml}, 0.1 \mathrm{mg} / \mathrm{ml})$ was added, giving a final substrate concentration of $0.049 \mathrm{~mm}$, and the mixture was incubated at $37^{\circ} \mathrm{C}$ for $30 \mathrm{~min}$. The reaction was stopped by the addition of $0.2 \mathrm{M}$-glycine$\mathrm{NaOH}$ buffer, $\mathrm{pH} 10.3(3 \mathrm{ml})$. Blanks were prepared by adding the enzyme solution after the glycine buffer.

4-Methylumbelliferone released was measured fluorimetrically on an Aminco-Bowman spectrophotofluorimeter (excitation at $364 \mathrm{~nm}$, fluorescence at $446 \mathrm{~nm}$ ). Units of specific activity were expressed as $\mu \mathrm{g}$ of 4-methylumbelliferone released/h per $\mathrm{mg}$ of protein at $37^{\circ} \mathrm{C}$.

Assay with phenolphthalein glucuronide. Enzyme solution $(0.1 \mathrm{ml})$ was preincubated with $0.2 \mathrm{M}$-sodium acetate buffer, pH5 $(0.1 \mathrm{ml})$, and water $(0.1 \mathrm{ml})$. Substrate $(0.1 \mathrm{ml}, 8 \mathrm{~mm})$ was added, giving a final substrate concentration of $2 \mathrm{mM}$, and the mixture was incubated at $37^{\circ} \mathrm{C}$ for $30 \mathrm{~min}$. The reaction was stopped by the addition of glycine- $\mathrm{NaCl}-\mathrm{Na}_{2} \mathrm{CO}_{3}$ buffer, pH10.7 $(3.6 \mathrm{ml})$. The composition of the buffer was $0.133 \mathrm{M}$-glycine- $0.067 \mathrm{M}-\mathrm{NaCl}-0.083 \mathrm{M}$ $\mathrm{Na}_{2} \mathrm{CO}_{3}$, adjusted to $\mathrm{pH} 10.7$ with $\mathrm{NaOH}$. The mixture was centrifuged at $2000 \mathrm{~g}$ for $30 \mathrm{~min}$ and the $E_{552}$ of the supernatant was read with a Zeiss PMQ11 spectrophotometer. Blanks were prepared by substituting water for substrate.

With purified enzyme preparations, $0.08 \%$ bovine serum albumin $(0.1 \mathrm{ml})$ was substituted for water in the reaction mixture.

Units of specific activity were expressed as $\mu \mathrm{g}$ of phenolphthalein released/h per $\mathrm{mg}$ of protein at $37^{\circ} \mathrm{C}$.

\section{Plasma activation tests}

'Platelet-free' plasma obtained by centrifuging heparinized $(0.1 \mathrm{mg} / \mathrm{ml})$ blood at $2000 \mathrm{~g}$ for $30 \mathrm{~min}$ was diluted with water (4vol.), heated at $100^{\circ} \mathrm{C}$ for $10 \mathrm{~min}$ and centrifuged at $2000 \mathrm{~g}$ for $30 \mathrm{~min}$. Various concentrations of the heated plasma supernatant were used in the $\beta$-glucuronidase assay mixtures in place of water.

$\beta$-Glucuronidase activity of plasma was measured in the diluted plasma samples $(0.1 \mathrm{ml})$ by the methylumbelliferone assay.

\section{Determination of protein}

This was done by the method of Lowry et al. (1951), with bovine serum albumin as standard. The elution of protein from columns was monitored by $E_{280}$ measurements.

\section{Column chromatography}

Sephadex gel-filtration and Whatman ion-exchange cellulose columns were prepared according to the manufacturer's instructions. They were equilibrated in tris- $\mathrm{HCl}$ buffer, $\mathrm{pH} 7.8(I=0.05)$, before use, and flow rates were controlled by a peristaltic pump (LKB).

\section{Disc electrophoresis}

Disc electrophoresis was performed on polyacrylamide gels (Davis, 1964) without sample gels. A tris-glycine buffer system was used, giving pH9.5 during electrophoresis; the current was $5 \mathrm{~mA}$ /tube. The gels were run until $5 \mathrm{~min}$ after the Bromophenol Blue marker had disappeared and were then stained with Amido Black.

\section{Results}

\section{Purification of lysosomal $\beta$-glucuronidase}

Purification in parallel with cathepsin D. During the preparation of placental lysosomal cathepsin D (Barrett, 1967), we examined the enzyme residues for contamination by other lysosomal enzymes and found that $\beta$-glucuronidase was present with high specific activity. This led us to adopt this method as a purification procedure for lysosomal $\beta$-glucuronidase. The method used was identical with Barrett's (1967)

Table 1. Purification of lysosomal $\beta$-glucuronidase from human placenta by a modification of the method of Barrett (1967)

Experimental details are given in the text.

$\begin{array}{lcc} & \begin{array}{c}\text { Specific } \\ \text { activity } \\ \text { (units) }\end{array} & \text { Purification } \\ \text { Homogenate } & 2.09 & 1 \\ \text { Acetone-dried powder } & 21.0 & 10 \\ \text { Dialysis residue } & 274 & 131 \\ \text { DEAE-Sephadex } & 494 & 236 \\ \text { Sephadex G-100 } & 4400 & 2105\end{array}$


method, and consisted of the preparation of an acetone-dried powder from the lysosomal fraction, the extraction of the powder with formate buffer,

Table 2. Purification of lysosomal $\beta$-glucuronidase on DEAE-cellulose

Experimental details are given in the text.

Specific activity (units)

Homogenate Lysosomal fraction DEAE-cellulose

$\begin{array}{rc}1.60 & 1 \\ 6.64 & 4.15 \\ 2120 & 1325\end{array}$

dialysis of the extract, and protein separations on columns of DEAE-Sephadex A-50 and Sephadex G-100 equilibrated in tris- $\mathrm{HCl}$ buffer, pH7.8 ( $I=$ $0.05)$. The $\beta$-glucuronidase was eluted from the Sephadex A-50 column by tris $-\mathrm{HCl}$ buffer, whereas cathepsin $\mathrm{D}$ was eluted by $0.05 \mathrm{M}-\mathrm{NaCl}$ in the buffer. Purifications achieved are shown in Table 1.

Purification on DEAE-cellulose. In some cases, a partial purification of lysosomal $\beta$-glucuronidase was achieved by using Whatman DE52 cellulose. Lysosomal extracts were dialysed against $5 \mathrm{mM}-\mathrm{Na}_{2} \mathrm{HPO}_{4}$ buffer, pH8.7, and portions $(20 \mathrm{ml})$ were applied to columns $(28 \mathrm{~cm} \times 1.4 \mathrm{~cm})$ of DE52 cellulose, equilibrated in $5 \mathrm{mM}-\mathrm{Na}_{2} \mathrm{HPO}_{4}, \mathrm{pH} 8.7$, and allowed to

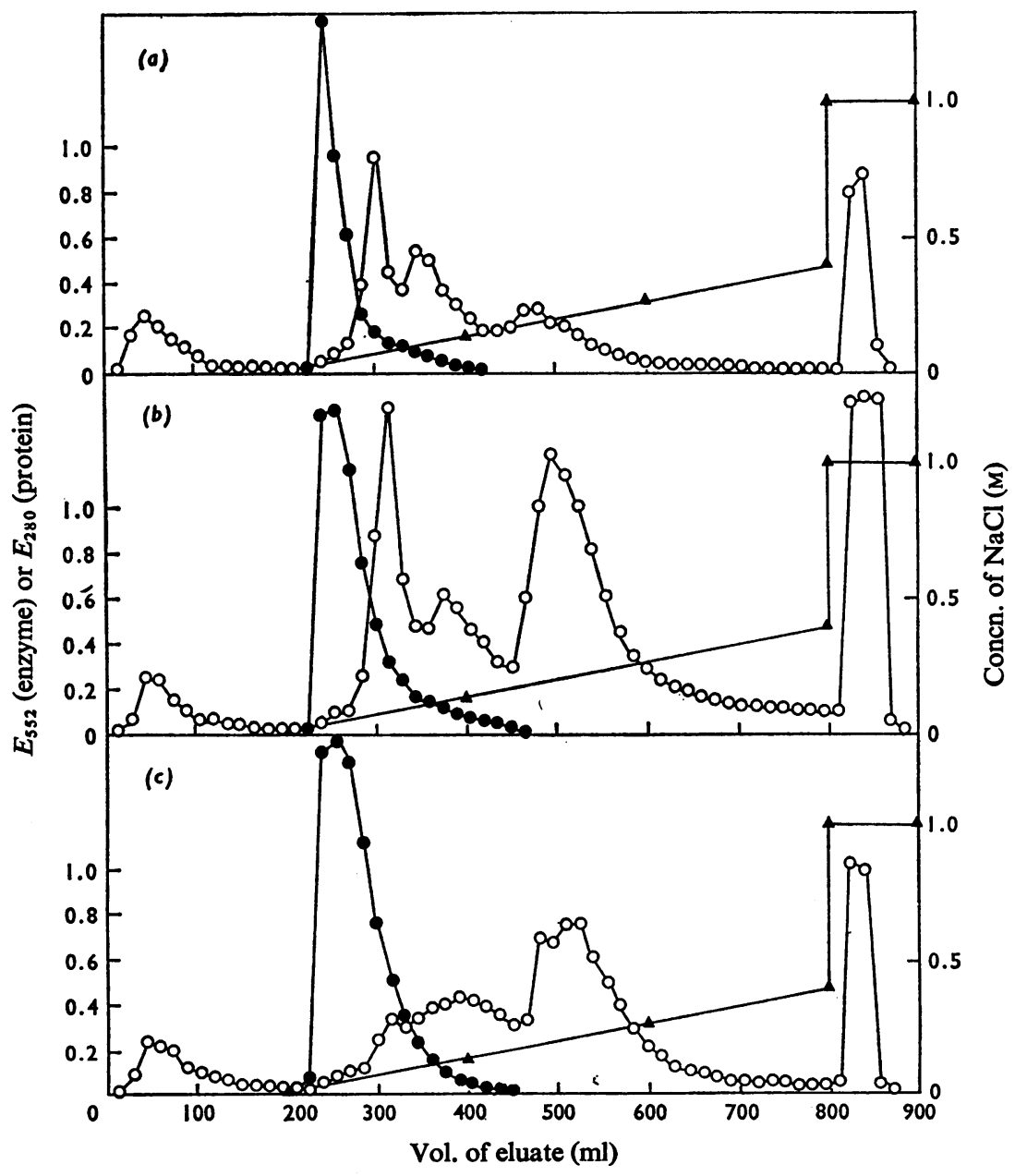

Fig. 1. Elution of $\beta$-glucuronidase $(\bullet)$ and protein $(0)$ of placental subcellular fractions from DE52 cellulose columns

The columns $(28 \mathrm{~cm} \times 1.4 \mathrm{~cm})$ were equilibrated in $5 \mathrm{mM}-\mathrm{Na}_{2} \mathrm{HPO}_{4}, \mathrm{pH} 8.7$, and were eluted with $5 \mathrm{mM}-\mathrm{Na}_{2} \mathrm{HPO}_{4}$, pH 8.7, followed by a linear gradient of $\mathrm{NaCl}$ in $5 \mathrm{mM}-\mathrm{Na}_{2} \mathrm{HPO}_{4}, \mathrm{pH} 8.7(\Delta)$. Experimental details are given in the Results section. (a) Homogenate; (b) nuclear pellet; (c) lysosomal pellet.

Vol. 128 
drain in. Columns were eluted with $5 \mathrm{~mm}-\mathrm{Na}_{2} \mathrm{HPO}_{4}$, pH $8.7(200 \mathrm{ml})$, followed by a $0-0.4 \mathrm{M}-\mathrm{NaCl}$ linear

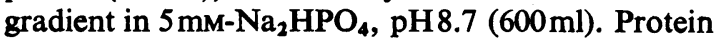
remaining on the columns was eluted with $1 \mathrm{M}-\mathrm{NaCl}$ in the buffer $(100 \mathrm{ml})$. Results from a typical experiment are shown in Table 2 and Fig. 1. $\beta$-Glucuronidase was eluted at the start of the $\mathrm{NaCl}$ gradient.

No loss of enzyme activity was detected in samples stored at room temperature for 3 days at pH 8.7.

\section{Properties of the enzyme}

Homogeneity. Purified enzyme samples were subjected to disc electrophoresis in a discontinuous tris-glycine buffer system (Davis, 1964). The purified preparation contained a single major band corresponding to protein and $\beta$-glucuronidase activity.

Effect of $\mathrm{pH}$ on activity. $\mathrm{pH}$-activity curves were determined for the lysosomal enzyme at different stages of purification, with various concentrations of phenolphthalein glucuronide as substrate. Maximum activity for the crude lysosomal enzyme was achieved at $\mathrm{pH} 5$ with a substrate concentration of $2 \mathrm{~mm}$. Dialysis changed the optimum conditions to $\mathrm{pH} 4.0$ and $1 \mathrm{~mm}$ substrate and caused a slight increase in absolute activity. The purified enzyme preparations in the absence of albumin had maximum activity at pH 5.0 with $2 \mathrm{~mm}$ substrate (Fig. 2).

With methylumbelliferyl glucuronide as substrate at conditions considerably less than optimum, a $\mathrm{pH}$ optimum of 3 was found for placental homogenate, placental lysosomal fraction and plasma from pregnant and non-pregnant women (Fig. 3).

Effect of albumin and plasma on activity. Heated plasma supernatant and albumin had an activating effect on placental $\beta$-glucuronidase under certain conditions.

With phenolphthalein glucuronide as substrate, heated plasma supernatant had little effect on optimum conditions for the enzyme assay with crude lysosomal and dialysed preparations. However, activation of the enzyme was found in the $\mathrm{pH}$ range $3-4.25$. The activation in this $\mathrm{pH}$ range was very marked when high substrate concentrations $(5 \mathrm{mM})$, which normally inhibit the enzyme at lower $\mathrm{pH}$ values, were used. At pH5, a slight inhibition of enzyme activity was noticed in the presence of heated plasma supernatant.

Heated plasma supernatant and albumin had a marked effect on the activity of the purified $\beta$ glucuronidase preparations. Both caused a large activation in enzyme activity and a shift in the $\mathrm{pH}$ optima to give a broad optimum of $\mathrm{pH} 3-4.5$, with an apparent maximum at pH3.5 (Fig. 2).

In the methylumbelliferyl glucuronide assay, heated plasma supernatant had a considerable activating effect on the placental enzyme (Fig. 3). The pH optimum of 3 was unchanged and no differences in

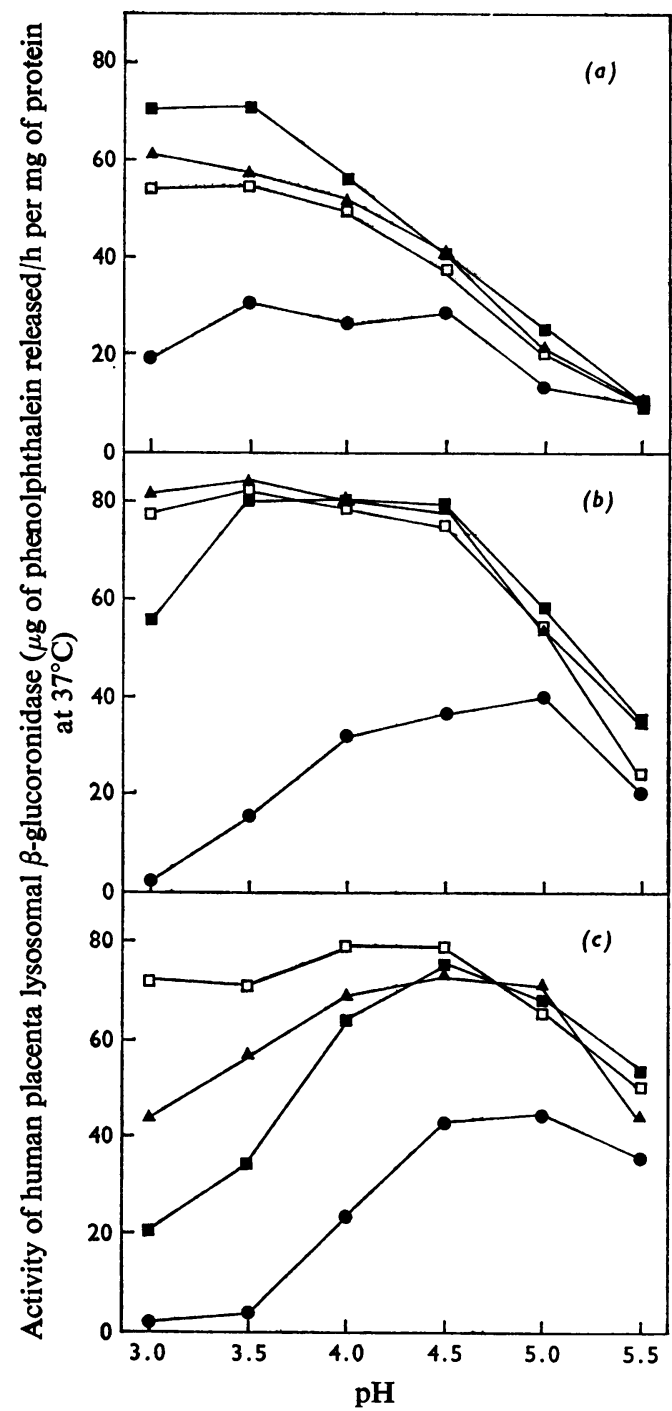

Fig. 2. Effect of $p H$, phenolphthalein glucuronide concentration, heated plasma supernatant $(2 \mu l)$ and albumin $(0.02 \%)$ on the activity of a purified lysosomal $\beta$-glucuronidase preparation $(7.3 \mu \mathrm{g})$

Assay conditions are described in the text. $\bullet$, No addition; $\mathbf{\square}$, plus heated plasma supernatant; $\Delta$, plus albumin; $\square$, plus heated plasma supernatant and albumin. (a) $0.25 \mathrm{~mm}$-Substrate; (b) $1 \mathrm{~mm}$-substrate; (c) 2 mM-substrate.

activating properties were detected between heated plasma supernatant from pregnant and non-pregnant women. The activation was most marked at very low 


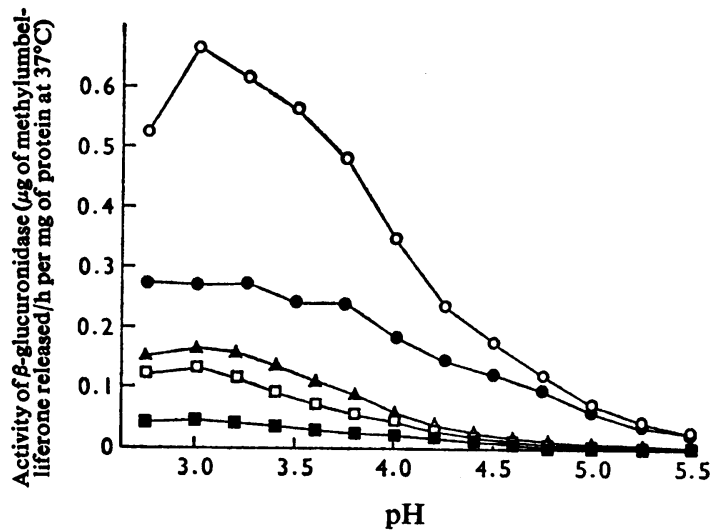

Fig. 3. Effect of $p H$ on the activity of various $\beta$ glucuronidase preparations with methylumbelliferyl glucuronide $(0.049 \mathrm{mM})$ as substrate

Assay conditions are described in the text. Plasma from non-pregnant women; $\square$, plasma from pregnant women; $\Delta$, placental homogenate; $\bullet$, lysosomal fraction; 0 , lysosomal fraction plus heated plasma supernatant $(2 \mu 1)$.

enzyme concentrations and was presumably caused mainly by a reassociation of enzyme subunits.

However, the specific activities of more concentrated enzyme solutions were increased in the presence of plasma, demonstrating that the activation was 'real' (Fig. 4).

\section{Activators and inhibitors in plasma}

Non-heated plasma activated placental enzyme to the same extent as did heated plasma supernatant, when allowance was made for the enzyme activity of the non-heated sample, demonstrating that heating at $100^{\circ} \mathrm{C}$ did not form an activator for placental $\beta$-glucuronidase.

After dialysis of the heated plasma supernatant sample against water, the dialysis residue retained all its activation properties.

Addition of heated plasma supernatant to plasma enzyme resulted in a decrease in enzyme activity. With methylumbelliferyl glucuronide as substrate the $K_{m}$ value for the plasma enzyme increased, but $V_{\max }$. was unaffected. When the total concentration of heated plus non-heated plasma was kept constant, the enzyme activity was proportional to the concentration of non-heated plasma, demonstrating the presence in plasma of a competitive inhibitor of $\beta$-glucuronidase that is not formed as a result of heating plasma at $100^{\circ} \mathrm{C}$.

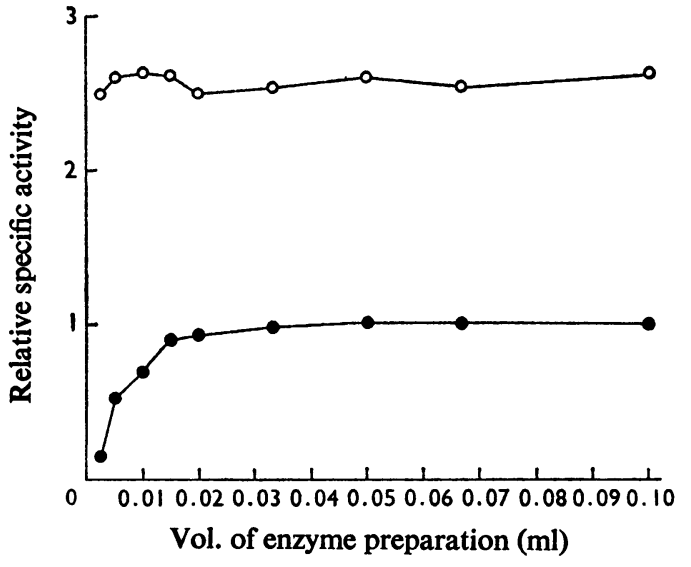

Fig. 4. Effect of dilution and heated plasma supernatant $(2 \mu l)$ on the specific activity of a placental lysosomal enzyme preparation

Enzyme activity was measured in a volume of $1 \mathrm{ml}$ with methylumbelliferyl glucuronide as substrate, by the technique described in the Materials and Methods section, except that reaction times were decreased for some of the assays to prevent excessive hydrolysis of substrate. The specific activity obtained by using $0.1 \mathrm{ml}$ of enzyme preparation in the assay mixture in the absence of heated plasma supernatant has been arbitrarily defined as 1 . ๑, No addition; 0 , plus heated plasma supernatant.

\section{Heat stability of enzyme preparations}

At $\mathrm{pH} 5$ and $\mathrm{pH} 7$ enzyme preparations from placental homogenate and lysosomes were resistant to heating; they retained at least $80 \%$ activity on heating for $60 \mathrm{~min}$ at $70^{\circ} \mathrm{C}$. Plasma enzyme, however, was heat-labile, all activity being destroyed by heating at $70^{\circ} \mathrm{C}$ for $15 \mathrm{~min}$. No differences were detected between the heat-stabilities of plasma from pregnant and non-pregnant subjects. Heating at $\mathrm{pH} 3$ increased the heat-lability of all enzyme preparations.

Addition of plasma or heated plasma supernatant to placental preparations initially caused an activation of $\beta$-glucuronidase activity, as described above, but the placental enzyme lost its heat-stability.

$K_{m}$ values for the plasma enzyme did not change after different stages of heat inactivation.

\section{Subcellular distribution of $\beta$-glucuronidase in placenta}

Whole tissue homogenate, nuclear, lysosomal and post-lysosomal fractions of placental tissues were prepared as described in the Materials and Methods section. Each fraction was suspended in $20 \mathrm{ml}$ of

Vol. 128 
$0.1 \%$ Triton $\mathrm{X}-100$ and treated in an MSE homogenizer at full speed for $6 \times 30 \mathrm{~s}$, which was the optimum condition for release of bound enzyme activity. The distribution of activity in each fraction is shown in Table 3.

\section{Isoenzymes of $\beta$-glucuronidase}

Chromatography of the dialysed subcellular fractions on DE52 cellulose failed to reveal isoenzymes (Fig. 1). $\beta$-Glucuronidase from each fraction was eluted in an identical position and only one peak was detected with each sample.

$K_{m}$ values for $\beta$-glucuronidase, purified from the subcellular fractions of placenta, are shown in Table 4. Values were similar for each fraction with phenolphthalein glucuronide as substrate, although a slight difference was found in the nuclear endoplasmic reticulum and lysosomal fractions with methylumbelliferyl glucuronide as substrate.

Although enzyme activity in plasma was increased during pregnancy (non-pregnant: 0.407-0.951; pregnant: $1.27-5.62 \mu \mathrm{mol}$ of methylumbelliferone/min per litre), the $K_{m}$ values for the enzymes in plasma from

\section{Table 3. Subcellular distribution of $\beta$-glucuronidase in} human placenta

Fractions were prepared as described in the Materials and Methods section.

\section{Fraction}

Enzyme activity

$\begin{array}{ll}\text { Nuclear +endoplasmic reticulum } & 50-60 \\ \text { Lysosomal+mitochondrial } & 16-30 \\ \text { Post-lysosomal } & 20-24\end{array}$

pregnant and non-pregnant women were identical and different from that of the placental enzyme (Table 4).

\section{Discussion}

The preparation of subcellular fractions of a tough fibrous tissue such as human placenta presents problems in homogenization if cells are to be broken with minimal damage to their subcellular constituents. Contractor's (1969) method, involving tissue mincing and homogenization in a nitrogen bomb, enables the homogenization of such tissue in relatively large quantities under better controlled conditions than those afforded by conventional methods.

$\beta$-Glucuronidase has a dual localization in the cell, in lysosomes and in the microsomal fraction (Bartalos \& Györkey, 1963; Fishman et al., 1967). Other workers studying the intracellular distribution of this enzyme in muscular tissues, such as ox heart (Sottocasa et al., 1962), and by using conventional homogenizers have found a large proportion of the enzyme in the nuclear fraction. This was presumably due to incomplete homogenization, resulting in the presence in the nuclear fraction of whole cells and also fragments of endoplasmic reticulum (Avis, 1969). We also have found a large proportion of the enzyme distributed in the nuclear fraction (Table 3) and our explanation is that the gentler technique of homogenization by the nitrogen bomb gives larger fragments of endoplasmic reticulum, which are spun down with the nuclei. Electron micrographs of the nuclear pellet showed the presence of rough endoplasmic reticulum, and phase-contrast microscopy demonstrated that the nuclear fraction was almost free of whole cells. Only $20-30 \%$ of the enzyme was distributed in placental lysosomes; the remainder was in the endoplasmic reticulum.

Table 4. Michaelis constants for $\beta$-glucuronidase in various preparations with phenolphthalein glucuronide and methylumbelliferyl glucuronide as substrates

Experimental details are given in the text.

\begin{tabular}{|c|c|c|c|c|c|}
\hline \multirow[b]{3}{*}{ Preparation } & \multirow[b]{3}{*}{$\mathrm{pH} \quad \ldots$} & \multicolumn{4}{|c|}{$K_{m}(\mathrm{mM})$} \\
\hline & & \multicolumn{3}{|c|}{ Phenolphthalein glucuronide } & \multirow{2}{*}{$\begin{array}{c}\text { Methylumbelliferyl } \\
\text { glucuronide } \\
3.0\end{array}$} \\
\hline & & 3.5 & 4.5 & 5.0 & \\
\hline \multicolumn{6}{|l|}{ Placental } \\
\hline Homogenate & & 0.39 & 0.36 & 0.83 & 0.045 \\
\hline Nuclear +endoplasmic reticulum & & 0.36 & 0.38 & 0.66 & 0.050 \\
\hline Lysosomal + mitochondrial & & 0.38 & 0.34 & 0.68 & 0.041 \\
\hline Post-lysosomal & & 0.33 & 0.31 & 0.76 & - \\
\hline \multicolumn{6}{|l|}{ Plasma } \\
\hline Non-pregnant & & - & - & - & $0.060-0.063$ \\
\hline Pregnant & & - & - & - & $0.062-0.065$ \\
\hline
\end{tabular}


The assay with phenolphthalein glucuronide used in this study has been extensively used by other workers (Fishman, 1967) and has been found to be simple and reliable. The assay with methylumbelliferyl glucuronide has been used only rarely, although the high sensitivity of a fluorimetric method would seem to make it the assay of choice for tissues such as plasma, where only low concentrations of $\beta$ glucuronidase are present. However, although we have found this assay simple to carry out, there are drawbacks in its use, which have prevented us using it on a more routine basis. The high sensitivity of the assay and fluorescence of blanks necessitates the use of low, sub-optimum substrate concentrations and so care must be taken to ensure that only a small amount of the substrate is hydrolysed in the reaction time. The method is also susceptible to relatively low concentrations of ions; $15 \mathrm{mM}-\mathrm{NaCl}$ or $-\mathrm{KCl}$ causes $50 \%$ inhibition. Even the buffer used in this assay $(0.04 \mathrm{M}$-sodium acetate, $\mathrm{pH} 3)$ resulted in a $10 \%$ inhibition of enzyme activity, and lower buffer concentrations resulted in a loss of buffering power.

Fishman (1967) has reviewed several reports of elevated plasma $\beta$-glucuronidase activity in pregnancy and has suggested that there is a placental contribution to this increase. Woollen \& Turner (1965) came to the same conclusion. With methylumbelliferyl glucuronide as substrate, they found that the $K_{m}$ value of $\beta$-glucuronidase in maternal plasma differed from that of normal plasma, and approximated to that of the placenta. However, our results do not substantiate this view. With the same substrate, but at an incubation $\mathrm{pH}$ of 3 rather than 3.6 (Fig. 3), we also have found an increase of $\beta$-glucuronidase activity in the plasma of pregnant women; however, our $K_{m}$ values for plasma from both pregnant and non-pregnant women were identical, but different from those obtained from placental homogenate and placental subcellular fractions (Table 4). It appears therefore that the elevated plasma isoenzyme concentrations found in pregnancy are due to an increase in the normal plasma isoenzyme concentration and are not caused by contribution from placental isoenzyme activity. The heat-stability results show that the plasma enzymes from pregnant and non-pregnant women were both heat-labile at $70^{\circ} \mathrm{C}$, whereas placental enzyme was heat-stable. Also, the $K_{m}$ value for the plasma enzyme in each case did not change during the process of heat inactivation, so there was no evidence of an additional isoenzyme (with a heat-stability different from that of the normal plasma isoenzyme) in plasma obtained during pregnancy, supporting our conclusion that plasma and placenta contain two different enzymes. Addition of plasma or heated plasma supernatant to placental enzyme destroyed its stability to heat, but the significance of this is not clear. Heating plasma did not form an inhibitor, so possibly the 'protective' mechanism in the placental extract was inactivated by the addition of plasma. Huddleston et al. (1971), used starch-gel electrophoresis and demonstrated that a single isoenzyme of $\beta$-glucuronidase was increased in gestational sera and that this isoenzyme was different from placental isoenzyme.

Although the purified lysosomal $\beta$-glucuronidase obtained in this study appeared homogeneous on polyacrylamide gels, its final specific activity was much lower than that obtained by other workers investigating mammalian $\beta$-glucuronidase (Levvy \& Conchie, 1966). However, the increase in specific activity of greater than 2000-fold, obtained over the placental homogenate (Table 1), was considered sufficient to enable us to characterize the lysosomal $\beta$-glucuronidase. The specific activity of pure placental lysosomal isoenzyme may be lower than that in other mammalian organs.

In our studies on placental subcellular fractions we did not detect any isoenzymes of $\beta$-glucuronidase by column chromatography (Fig. 1), and pooled enzyme ran as a single band on disc electrophoresis. Also, no significant differences were found in the $K_{m}$ values of enzyme purified from the various subcellular fractions of placenta (Table 4). The small differences found with the phenolphthalein glucuronide assay (Table 4) were probably caused by the difficulty in drawing a Lineweaver-Burk plot, as $\beta$-glucuronidase activity is inhibited by substrate.

The affinity of methylumbelliferyl glucuronide for the enzyme was greater at $\mathrm{pH} 3$ than at $\mathrm{pH} 3.6$ and consequently the $K_{m}$ values reported by us for plasma (Table 4) are much lower than the values of 0.21 $0.29 \mathrm{~mm}$ reported by Woollen \& Turner (1965). Increased substrate concentration increased the optimum $\mathrm{pH}$, as a result of substrate inhibition.

Although maximum activity for crude enzyme preparations was at $\mathrm{pH} 5$, the affinity of phenolphthalein glucuronide for the enzyme was greater at pH3.5 and 4.5 (Table 4). It appears, as noted by Mills et al. (1953), that substrate inhibition is more marked at the lower $\mathrm{pH}$ values.

The activating effect of albumin on purified enzyme samples is well known (Levvy \& Conchie, 1966). It is believed to cause a recombination of enzyme subunits in dilute solution and consequently has little effect on crude enzyme preparations. We have also found this activating effect on dilute, purified enzyme preparations (Fig. 2), but, whereas other workers have found no change in pH optima (Levvy \& Conchie, 1966), we have found a marked shift towards the lower $\mathrm{pH}$ values (Fig. 4). Activation by albumin seems to be maximal in the range pH3-3.5, although the reason for this unexpected observation is not clear.

Plasma and heated plasma supernatant from both pregnant and non-pregnant women also had an activating effect on placental $\beta$-glucuronidase. The plasma activator was heat-stable, non-diffusible on 
dialysis and caused a 'true activation' of enzyme, as it increased the specific activity of fairly concentrated enzyme preparations (Fig. 4). Plasma caused greatest activation with dilute enzyme samples, but this was probably a reassociation effect and could have been caused by the albumin present. Albumin and plasma seemed to decrease the inhibitory effect of phenolphthalein glucuronide between $\mathrm{pH} 3$ and 4.

A heat-stable competitive inhibitor of $\beta$-glucuronidase, present in plasma, was detectable by its effect on both the plasma enzyme and the crude placental enzyme at pH5. This was presumably the nondiffusible 'antiglucuronidase' described by Fishman (1967).

The presence of an isoenzyme of $\beta$-glucuronidase in the placenta, with quite different properties from the serum $\beta$-glucuronidases, could form the basis for a placental function test. At the limits of sensitivity of our assay procedure we have not been able to detect this enzyme in the serum of normal pregnant women. The development of a sensitive and specific assay of this isoenzyme in serum by, for example, radioimmunoassay could yield a method for assessing cellular damage in a placenta under pathological conditions, when one would expect the enzyme to leak out of the trophoblastic cells and into the maternal circulation.
We thank Mr. J. T. Syrett for the electron microscopy, Roche Products Ltd. for a generous grant to B. S., and the Wellcome Foundation for the ultracentrifuge.

\section{References}

Avis, P. J. G. (1969) in Subcellular Components (Birnie, G. D. \& Fox, S. M., eds.), p. 1, Butterworths, London Barrett, A. J. (1967) Biochem. J. 104, 601

Bartalos, M. \& Györkey, F. (1963) J. Amer. Geriat. Soc. 11, 21

Contractor, S. F. (1969) Nature (London) 223, 1274

Davis, B. J. (1964) Ann. N.Y. Acad. Sci. 121, 404

Fishman, W. H. (1967) Methods Biochem. Anal. 15, 78

Fishman, W. H., Goldman, S. S. \& De Lellis, R. (1967) Nature (London) 213, 457

Huddleston, J. F., Lee, G. \& Robinson, J. C. (1971) Amer. J. Obstet. Gynecol. 109, 1017

Levvy, G. A. \& Conchie, J. (1966) in Glucuronic Acid (Dutton, G. J., ed.), p. 301, Academic Press, New York

Levvy, G. A. \& Marsh, C. A. (1959) Advan. Carbohyd. Chem. 14, 381

Lowry, O. H., Rosebrough, N. J., Farr, A. L. \& Randall, R. J. (1951) J. Biol. Chem. 193, 265

Mills, G. T., Paul, J. \& Smith, E. E. B. (1953) Biochem. J. 53,232

Sottocasa, G. L., Stagni, N., Romeo, D. \& de Bernard, B. (1962) Ital. J. Biochem. 11, 310

Woollen, J. W. \& Turner, P. (1965) Clin. Chim. Acta 12, 671 